\title{
Antiplasmodial Activity and Phytochemical Constituents of the Selected Antimalarial Plants Used by Native People in West Timor Indonesia
}

\author{
Batı Timor Endonezya'da Yerli Halkın Kullandığı Bazı Antimalarial Bitkilerin \\ Antiplazmodial Aktivitesi ve Fitokimyasal Bileşenleri
}

$\underline{\text { Maximus M Taek }}^{1}$, Gerardus D Tukan $^{1}$, Bambang Prajogo $^{2}, \underline{\text { Mangestuti Agil }}^{2}$

${ }^{1}$ Department of Chemistry, Faculty of Mathematics and Natural Sciences, Widya Mandira Catholic University, Kupang, Indonesia

${ }^{2}$ Department of Pharmacognosy and Phytochemistry, Faculty of Pharmacy, Airlangga

University, Surabaya, Indonesia

\begin{abstract}
Objectives: To document traditional antimalarial plants used by the Tetun ethnic people in West Timor Indonesia, and to evaluate the antiplasmodial activity and phytochemicals of several plants that are widely used as oral medicine.

Materials and Methods: A field study to document antimalarial plants followed by laboratory works to test antiplasmodial activity and identify the phytochemical constituents of some selected plants extract were applied. Ethanolic extracts of Strychnos ligustrina wood, roots of Calotropis gigantea, Fatuoa pilosa and Neoalsomitra podagrica, whole plant of Cleome rutidosperma and Physalis angulata, stem barks of Alstonia spectabilis, Alstonia scholaris, Jatropha curcas and Plumeria alba, and leaves of Melia azedarach were tested for their inhibitory potency on the Plasmodium falciparum 3D7 strain in vitro. The phytochemicals of the extracts were analyzed with a GC-MS instrument.
\end{abstract}

Results: There were 50 species of plants used as antimalarial by the Tetun ethnic people. Extracts of $P$. angulata, J. curcas and A. spectabilis showed a strong antiplasmodial activity with the $\mathrm{IC}_{50}$ values of $0.22,0.22$ and $1.23 \mu \mathrm{g} / \mathrm{mL}$, respectively. The $N$. podagrica, $A$. scholaris, F. pilosa and P. alba were moderate antiplasmodials with the $\mathrm{IC}_{50}$ of 11.60 , $15.46,24.92$, and $36.39 \mu \mathrm{g} / \mathrm{mL}$, respectively, and C. rutidosperma, M. azedarach, $S$. ligustrina and C. gigantea were weak antiplasmodials with the $\mathrm{IC}_{50}$ of 54.25, 63.52, 63.91 and $66.49 \mu \mathrm{g} / \mathrm{mL}$, respectively. Data of the phytochemicals identification indicate that these 11 plants contain alkaloids, terpenoids, steroids, coumarins, alcohols, thiols, phenolics, aldehydes, fatty acids, esters, etc.

Conclusion: Plants that widely used as antimalarial by the Tetun ethnic people have been proven to have antiplasmodial activity.

Key words: Ethnomedicine, medicinal plant, malaria, antiplasmodial activity

ÖZ

Amaç: Endonezya Batı Timor'unda Tetun tarafından kullanılan geleneksel antimalarial bitkileri belgelemek ve yaygın olarak oral ilaçlar olarak kullanılan bazı bitkilerin antiplazmodial ve fitokimyasal aktivitelerini değerlendirmek.

Gereç ve Yöntemler: Antimalarial bitkileri belgeleyen bir alan çalışmasını, antiplazmodial aktiviteyi test etmek ve seçilen bitki ekstraktlarından fitokimyasal bileşenleri belirlemek için laboratuvar çalışması izlemiştir. Gelen etanolik ekstreler Strychnos ligustrina, Calotropis 
gigantea, Fatuoa pilosa ve Neoalsomitra podagrica, Cleome rutidosperma, Physalis angulata, Alstonia spectabilis, Alstonia scholaris, Jatropha curcas, Plumeria alba ve Melia azedarach tüm parçaları suşu üzerine inhibitör kuvvete bunları test 3D7 Plasmodium falciparum in vitro olarak. Fitokimyasal ekstreler GC-MS cihazları ile analiz edildi.

Bulgular: Tetun etnik halkı tarafından antimalarial olarak kullanılan 50 bitki türü vardı. $P$. angulata, J. curcas ve A. spectabilis'in özleri, sirasiyla $0.22,0.22$ ve $1.23 \mu \mathrm{g} / \mathrm{mL} \mathrm{IC}_{50}$ değerleriyle güçlü bir antiplazmodial aktivite göstermiştir. $N$. podagrica, A. scholaris, $F$. pilosa ve $P$. alba, sirasiyla $11.60,15.46,24.92$ ve $36.39 \mu \mathrm{g} / \mathrm{mL} \mathrm{IC}_{50}$, ve $C$. rutidosperma, $M$. azedarach, S. ligustrina ve C. gigantea, $\mathrm{IC}_{50}$ ile sirasiyla 54.25, 63.52, 63.91 ve 66.49 $\mu \mathrm{g} / \mathrm{mL}$ zayıf antiplazmodiyallerdi. Fitokimyasal tanımlamanın verileri, bu 11 bitkinin alkaloitler, terpenoidler, steroidler, kumarinler, alkoller, tiyoller, fenolikler, aldehitler, ya $\breve{g}$ asitleri, esterler ve diğer bileşikleri içerdiğini gösterir.

Sonuçlar: Tetun etnik halkı tarafından yaygın olarak antimalarial olarak kullanılan bitkilerin antiplazmodial aktivite gösterdiği kanıtlanmıştır.

Anahtar kelimeler: Etnomedicine, şifalı bitki, sıtma, antiplazmodial aktivite

Maximus M Taek, Department of Chemistry, Faculty of Mathematics and Natural Sciences, Widya Mandira Catholic University, Kupang, Indonesia maximusmt2012@gmail.com

0000-0002-4597-2167

$+6282245811193$

22.10 .2019

26.12.2019

\section{INTRODUCTION}

Plants are a very valuable source for obtaining various pharmacological active substances to deal with various human health problems. ${ }^{1}$ For thousands of years, plants have been the basis and important part of various traditional medical systems. It is estimated that of the total number of plant species known today, around $25 \%$ or $40,000-70,000$ species are used as medicinal plants by people in various places all over the world. ${ }^{2,3}$

More recently, natural product chemicals isolated from plants have been a good source of lead compound to treat various infectious diseases, including malaria. Quinine isolated from Cinchona sp. stem bark and artemisinin from Chinese medicinal plants Artemisia annua are two examples of lead compounds that are phenomenal and have contributed greatly to reducing deaths of malaria all over the world. ${ }^{4}$ From quinine, various derivatives such as chloroquine, amodiaquine, primaquine, and mefloquine have been synthesized; and from artemisinin, several compounds have been produced, namely artemether, arteether, and sodium artesunate. However, since the last few decades, Plasmodium has shown increasing resistance to antimalarial quinine derivatives, especially chloroquine, and made them no longer effective. Several recent publications have even reported that Plasmodium falciparum has also shown an increase in resistance to artemisinin-based antimalarials. ${ }^{5}$ The fact that Plasmodium's increasing resistance to antimalarial drugs currently used, has encouraged the researchers to continue searching for new and more effective antimalarials. ${ }^{6}$ Plants in traditional medicine of various ethnics all over the world have become one of the most important sources in searching of new potential antimalarials. ${ }^{7}$ Selecting plants that have been traditionally used to treat malaria is a promising and better approach to find new antimalarial(s). This saves more resources such as high investment and skills, and has also 
been shown to has accelerated the time of the plant selection and test of its antimalarial activity compared to random selection approach. Research on medicinal plants of various traditional medicine systems could provide useful leads for the development of important active antimalarials. $^{8}$

The experience of the Tetun people - a native ethnic in West Timor interacting with malaria since long time ago led to them having developed their own methods to treat malaria. The Tetun people identify malaria as sick of hot body or fever. Traditional treatment of malaria by the Tetun community is carried out using a variety of medicinal plants formula called $a i$ tahan or kwa, which are applied by drinking, bathing, massage, inhaling, and cataplasm. ${ }^{9}$ Indepth exploration of the antimalarial plants used in traditional medicine of the Tetun ethnic community might provide a valuable contribution to the discovery of new sources of antimalarial substances.

This research is an ethnomedicine study that was first conducted in the Tetun community. In our study, we conducted two steps of research. First, we conducted a field research to document various species of medicinal plants and formula of traditional medicines used by the Tetun people to treat malaria orally. In the second step, we selected some of the high frequency mentioned plants for testing their antiplasmodial activity. Antiplasmodial activity testing was carried out in vitro against chloroquine sensitive Plasmodium falciparum 3D7 strain.

\section{MATERIALS AND METHODS Field study}

The field research was carried out in several sub-districts of Belu District $\left(9^{\circ} 15^{\prime} 0^{\prime \prime} \mathrm{S}\right.$, $\left.124^{\circ} 40^{\prime} \mathrm{E}\right)$ and Malaka District $\left(9^{\circ} 34^{\prime} \mathrm{S}, 124^{\circ} 54^{\prime} \mathrm{E}\right)$. These two districts are located along the borderline of East Nusa Tenggara Province (Indonesia) and Republic Democratic de Timor Leste. In this field study, we collected information through some interviews and discussions. Ninety-four informants, 42 male and 52 female were involved in this study. They consist of traditional healers, former malatia sufferers who have undergone traditional medicine, and other people who have knowledge and experience in traditional treatment of malaria. These informants were aged between 40-90 years old, and almost all of them have settled in their place since they were born

Data collected relating to traditional medicinal plants used for the treatment of malaria include: the local name of the plant, the place of obtaining the plant, the part of the plant used as a medicine, the method of processing and use, the dosage and duration of use, and the claimed effect of the medication. Each of the plants informed by the informants was then collected in parts to prepare a herbarium. All of the plants were identified, firstly by matching their local name with scientific name of species listed in book of Timorese local plants. ${ }^{10}$ Secondly, those plants were identified again by the expert of Lembaga Ilmu Pengetahuan Indonesia (LIPI)-Bogor Botanic Garden. Part(s) of some plants with high frequency of mention by the informants were collected in greater quantities. Those samples of the plant's part were collected from the area where the plant was mentioned.

\section{Preparation of the plants extract}

The plant's part samples i.e. whole plant, stem bark, wood, roots or leaves were cleaned from attached dirt using tap water. The samples were then air-dried at room temperature until they were completely dry, then grounded into powder. The extracts were prepared by maceration. A $20 \mathrm{~g}$ of each plant powder was macerated with $95 \%$ ethanol for $24 \mathrm{~h}$ at room temperature, and then filtered. The maceration was repeated for three times, and the filtrates were collected and then evaporated to dry using a vacuum rotary evaporator at $40^{\circ} \mathrm{C}$. These dried extracts were stored well in a closed container, and then used for antiplasmodial activity test against Plasmodium falciparum, and for phytochemicals analysis.

\section{In vitro antiplasmodial activity test}


Testing of antimalarial activity was carried out in vitro on the chloroquine sensitive 3D7 strain of Plasmodium falciparum obtained from the Institute of Tropical Diseases Airlangga University, Surabaya Indonesia. Plasmodium was cultivated in 96 microwells plate according to the method developed by Trager-Jensen. ${ }^{11}$ Cultivation of Plasmodium was carried out using human red blood cells $\mathrm{O}$ type with 5\% haematocrit suspended in RPMI 1640 medium. The culture was then incubated in a $\mathrm{CO}_{2}$ incubator at $37^{\circ} \mathrm{C}$, and the medium was replaced every day until parasitemia reaches 1-2\%. Dried plant extracts were dissolved in dimethylsulphoxide (DMSO) and filtered through a $0.22 \mu \mathrm{m}$ membrane filter. The solution of each extract was then put into microwells containing Plasmodium suspension with $1 \%$ parasitemia, then diluted with the RPMI 1640 medium in a series of ten-fold dillution to obtain the final concentrations of $100,10,1.0,0.1$ and $0.01 \mu \mathrm{g} / \mathrm{mL}$. Two series of controls were set up; one with parasitised blood cells without addition of plant extract -a negative control, and the other with parasitised blood cells added with chloroquine diphosphates -as positive control. The chloroquine diphosphates was prepared like plant extract to made final concentrations of $100,10,1.0,0.1$ and $0.01 \mu \mathrm{g} / \mathrm{mL}$. The culture then incubated in a $\mathrm{CO}_{2}$ incubator at $37^{\circ} \mathrm{C}$ for $48 \mathrm{~h}$. All tests were performed in duplicate. After $48 \mathrm{~h}$ of incubation, the culture of red blood cells was harvested. A thin blood smear was made on the glass object, then dried and fixed with methan 1 , and stained with Giemsa. The number of parasitised red blood cells were counted using a light microscope with 1000 times magnification.

Data obtained from this antiplasmodial activity was the number of infected red blood cells (iRBC) among a total of 1000s RBC counted, by observing blood smear slides under a microscope. The amount of $\mathrm{iRBC}$ to the total $\mathrm{RBC}$ was expressed as percentage of parasitemia, which was calculated using the numerical formula:

Percentage of parasitemia, $\mathrm{P}=[(\mathrm{iRBC} / \mathrm{RBC}) \times 100 \%]$

By the data of percentage of parasitemia in treated groups and negative control, then the percentage of growth and inhibition of Plasmodium were calculated, using the formula: Percentage of growth $=(\mathrm{Pt} / \mathrm{Pnc}) \times 100 \%$

Percentage of inhibition $=100 \%$ - percentage of growth

In those two later equations above, $P t$ stands for the percentage of parasitemia in treated groups, and Pnc is the percentage of parasitemia in negative control group. Pt and Pnc were calculated at the beginning of test $\left(0 \mathrm{~h}, \mathrm{P}_{0}\right)$ and when the culture was harvested $\left(48 \mathrm{~h}, \mathrm{P}_{48}\right)$. The actual percentage of parasitemia value was $\mathrm{P}_{48}-\mathrm{P}_{0}$. The range of the percentage of inhibition is $0 \%$ that means no inhibition, to $100 \%$ that is complete inhibition.

By plotting data of the percentage of inhibitions versus concentrations of each extract, the $50 \%$ inhibitory concentration $\left(\mathrm{IC}_{50}\right)$ was then calculated using probit analysis. The $\mathrm{IC}_{50}$ value was then compared to the value given by the literature to classify the antimalarial potency of each extract.

\section{Identification of phytochemicals in extracts}

Phytochemicals contained in each extract were analyzed using GC-MS. An Agilent 6980N Network GC System with autosampler was linked to a detector of Agilent 5973 inert MSD. A column of J\&W Scientific HP-5MS $30 \mathrm{~m}$ x $0,25 \mathrm{~mm}$ x $0,25 \mu \mathrm{m}$ was used. This GC-MS instrument used a Wiley version 7.0 database to interpreted the compounds. The operational conditions of the GC-MS was set up as follows: inlet temperature was $250^{\circ} \mathrm{C}$; oven tempeature was programmed at $50^{\circ} \mathrm{C}$ for $5 \mathrm{~min}$ and then increased $10^{\circ} \mathrm{C} / \mathrm{min}$ to $280^{\circ} \mathrm{C}$, which was maintained constant for $15 \mathrm{~min}$. Temperatures of Aux was $250^{\circ} \mathrm{C}$, MS Quad $150^{\circ} \mathrm{C}$, and MS Source $230^{\circ} \mathrm{C}$. Helium gas with purity of $99.999 \%$ was used as sample carrier. Gas flow in the column was set constant at $1.0 \mathrm{~mL} / \mathrm{min}$ for $50 \mathrm{~min}$ running time. Scan mode was ranged from 20 amu to $600 \mathrm{amu}$. 
Before running the analysis of the chemicals content, each extract was first dissolved in 5 $\mathrm{mL}$ ethanol, sonicated for $15 \mathrm{~min}$, and then filtered through a $0.45 \mu \mathrm{m}$ nylon membrane filter. The filtrate of $0.2 \mu \mathrm{L}$ was then injected in to the GC-MS system. After the analysis process in the instrument was finish, then the results were printed out.

\section{RESULTS AND DISCUSSION}

\section{Plants used for the treatment of malaria}

In this study, we have documented 50 plant species belong to 27 families that used for the treatment of malaria by the Tetun ethnic people in Malaka and Belu Districts (Table 1).

These plants were used in various recipes for oral application, as single formula or combination of plants. The The Strychnos ligustrina Blume, Calotropis gigantea (L.) R. Br., Cleome rutidosperma DC., Physalis angulata L., Carica papaya L., Alstonia spectabilis R.Br., Alstonia scholaris (L.) R.Br., Melia azedarach L., Plumeria alba L., Swietenia macrophylla King and Momordica balsamina L. were some of plants that more frequently mentioned by the informants.

The higher numbers of the plants belong to seven families: Apocynaceae and Fabaceae (five species of each), Cucurbitaceae (four species), and Meliaceae, Moraceae, Euphorbiaceae, and Rubiaceae (three species, respectively). In the utilization of these plants as medicinal materials, the most widely used plant parts are stem bark (21 species), leaves (19 species), and root (11 species). Some plants are used more than one part at a time. Common mode of preparation of various formula of these plants for oral use are decoction and infusion.

\section{Selection of the plants for antiplasmodial activity test}

Eleven plants species with high frequency of citation were selected to be tested for their antiplasmodial activity. Those plants were Those plants were Strychnos ligustrina Blume (34.04\%), Calotropis gigantea (L.) R. Br. (24.47\%), Cleome rutidosperma DC. (18.09\%), Physalis angulata L. (18.09\%), Alstonia spectabilis R.Br. (17.02\%), Alstonia scholaris (L.) R.Br. (13.83\%), Melia azedarach L. (13.83\%), Fatoua pilosa Gaudich. (7.45\%), Jatropha curcas (6.38\%), Plumeria alba L. (6.38\%) and Neoalsomitra podagrica Steenis (4.26\%). Three other plants of high frequency of citation-Carica papaya L. (17.02\%), Swietenia macrophylla King (6.38\%) and Momordica balsamina L. (5.32\%) were not included to be tested for their antiplasmodial activity for several reasons. The C. papaya was not selected for antiplasmodial testing by the reason that it is a food plant that is consumed every day as a vegetable. The wild bitter melon M. balsamina was not included too because this plant was difficult to obtain in the field, very rarely cultivated, usually only grow wild and seasonal. The $S$. macrophylla was not included because according to the informants, the use of this plant seeds as an antimalarial medicine was not sourced from traditional practice of the ancestors of Tetun people.

\section{Antiplasmodial activity}

Figure 1 shows a graphically comparison of the ability of extracts to inhibit the growth of Plasmodium. From this graph, it can be seen that along with an increase of concentration, three extracts, Physalis angulata L., Jatropha curcas L. and Alstonia spectabilis R.Br. show a more significant increase in their inhibitory activity, compared to the other eight extracts. On average, the graph shows that a tenfold increase in concentration of these three extracts increases their antiplasmodial activity twice.

The antiplasmodial activity of each extract in the form of percentage of inhibition at each concentration level, and the $\mathrm{IC}_{50}$ values were listed in Table 2 . The $50 \%$ inhibitory concentration, $\mathrm{IC}_{50}$, represents the concentration that causes $50 \%$ reduction in Plasmodium growth. The smaller IC 50 value indicates the better antiplasmodial activity of an extract, and vice versa, the greater the $\mathrm{IC}_{50}$ indicates a low inhibitory activity. In the same experimental conditions, the positive control, chloroquine diphosphate, has an $\mathrm{IC}_{50}$ value of $0.005 \mu \mathrm{g} / \mathrm{mL}$. 
Ouattara et al. categorized an extract with $\mathrm{IC}_{50}$ value lower than $5 \mu \mathrm{g} / \mathrm{mL}$ as a very active or strong antiplasmodial, $5-50 \mu \mathrm{g} / \mathrm{mL}$ as active or moderate antiplasmodial, $50-100 \mu \mathrm{g} / \mathrm{mL}$ as less active or weak antiplasmodial, and the IC50 value that higher than $100 \mu \mathrm{g} / \mathrm{mL}$ as inactive. ${ }^{12}$ Based on these categories, the ethanolic extracts of Physalis angulata L. (IC50 $0.22 \mu \mathrm{g} / \mathrm{mL}$ ), Jatropha curcas L. (IC $500.22 \mu \mathrm{g} / \mathrm{mL}$ ) and Alstonia spectabilis R.Br. (IC 501.23 $\mu \mathrm{g} / \mathrm{mL}$ ) are strong antiplasmodials, while Neoalsomitra podagrica Steenis (IC50 11.60 $\mu \mathrm{g} / \mathrm{mL}$ ), Alstonia scholaris (L.) R.Br. (IC $5015.46 \mu \mathrm{g} / \mathrm{mL}$ ), Fatoua pilosa Gaudich. (IC 50 $24.92 \mu \mathrm{g} / \mathrm{mL}$ ) and Plumeria alba L. (IC $5036.39 \mu \mathrm{g} / \mathrm{mL}$ ) are moderates. The extracts of Cleome rutidosperma DC. (IC $5054.25 \mu \mathrm{g} / \mathrm{mL}$ ), Melia azedarach L. (IC $5063.52 \mu \mathrm{g} / \mathrm{mL}$ ), Strychnos ligustrina Blume ( $\mathrm{IC}_{50} 63.91 \mu \mathrm{g} / \mathrm{mL}$ ) and Calotropis gigantea (L.) R. Br. (IC 50 $66.49 \mu \mathrm{g} / \mathrm{mL}$ ) are weak antiplasmodial. In general, the ethanolic extracts of P. angulata L., J. curcas L. and A. spectabilis R.Br. showed good antiplasmodial effects on Plasmodium falciparum 3D7 strain, although they were relatively weaker than chloroquine diphosphate The ethanolic extract of Physalis angulata L. showed the strongest antiplasmodial activity among the eleven plant extracts. This result is in line with the findings of other previous study using methanol and dichloromethane extracts of P. angulata L. leaves, where, these two extracts presented a very high activity with $\mathrm{IC}_{50}<3 \mu \mathrm{g} / \mathrm{mL}$ against the chloroquine sensitive 3D7 and chloroquine resistant W2 strains of Plasmodium falciparum in vitro. The extracts of $P$. angulata showed also a good inhibition of parasitemia in vivo on mice infected by Plasmodium berghei. ${ }^{13}$

In this study, the ethanolic extract of Jatropha curcas L. stem bark showed strong antiplasmodial activity, equivalent to Physalis angulata L. In another study, it was found that mice infected by Plasmodium berghei treated with 250,500 , and $750 \mathrm{mg} / \mathrm{kg}$ body weight doses of aqueous extract of J. curcas L. stem bark caused the percentage of parasitemia decreased from 9.25 to $7.80 \%$, suggesting that the plant extract possesses antiplasmodial properties. ${ }^{14}$

Result of this study showed that ethanolic extract of Plumeria alba L. stem bark is a moderate antiplasmodial. Another study showed that water extract (300 mg/kg body weight) and dichloromethane-methanol extract ( $300 \mathrm{mg} / \mathrm{kg}$ body weight) of stem bark of this plant has reduced the level of parasitemia in mice infected by Plasmodium berghei to $16.4 \%$ and $20.0 \%$, respectively, in eight days of evaluation. ${ }^{15}$

Although the ethanolic extract of Alstonia scholaris (L.) R.Br. stem bark in this study showed a moderate activity only, the results of another study showed that methanolic extract of stem bark showed excellent antiplasmodial activity with $\mathrm{IC}_{50}$ of $0.1650 \pm 0.1100 \mu \mathrm{g} / \mathrm{mL}$ against Plasmodium falciparum 3D7 strain. ${ }^{16}$ The stem bark of $A$. scholaris (L.) R.Br. contains villalstonine and macrocarpamine alkaloids which are antimalarial active, with the IC50 values of 0.27 and $0.36 \mu \mathrm{M}$ respectively against chloroquine resistant $P$. falciparum $\mathrm{K} 1$ strain. ${ }^{17}$

In this study, ethanolic extracts of Strychnos ligustrina Blume, Calotropis gigantea (L.) R.Br., Cleome rutidosperma DC. and Melia azedarach L. showed weak activity against Plasmodium falciparum 3D7 strain, with $\mathrm{IC}_{50}>50 \mu \mathrm{g} / \mathrm{mL}$. However, in several other studies using different solvents for extraction, it was found that these plants showed a good antiplasmodial activity. Water extract of S. ligustrina Blume wood inhibited P. falciparum growth in vitro by $98.1 \%$ at a concentration of $1.0 \mathrm{mg} / \mathrm{mL}$, and was classified as a strong antiplasmodial. ${ }^{18}$ Methanolic extract of C. gigantea (L.) R.Br. leaves showed a moderate antimalarial activity with an $\mathrm{IC}_{50}$ value of $12.17 \mu \mathrm{g} / \mathrm{mL}$ against $P$. falciparum in vitro, and a very good activity against $P$. berghei in vivo. ${ }^{19}$ Ethanolic extract of $C$. rutidosperma DC. whole plant showed a moderate antimalarial activity with $\mathrm{IC}_{50}$ of $34.4 \mu \mathrm{g} / \mathrm{mL}$, and its water extract was less active with $\mathrm{IC}_{50}>100 \mu \mathrm{g} / \mathrm{mL}$ against chloroquine sensitive $P$. falciparum D10 strain in vitro. ${ }^{20}$ 
The results of this antimalarial activity evaluation did not linear to rank of the plants based on their percentage of citation listed in Table 1. The Strychnos ligustrina Blume, Calotropis gigantea (L.) R.Br., and Cleome rutidosperma DC. which were the most frequently mentioned by the informants, were actually turned out to show a weak antiplasmodial activity in the laboratory testing. However, it does not mean that claims about the effectiveness of these plants as antimalarials are incorrect. Possible causes of nonsynchronous data between frequency of citation by the informants and the laboratoric antiplasmodial evaluation of these plants can be explained as follows. Firstly, the use of ethanol as a solvent for extraction can cause differences in type and amount of antiplasmodial active compounds extracted into it, and then cause differences in the antiplasmodial activity shown by each plant extract. Secondly, the biochemical system in the human body is very different from the in vitro system, therefore, the results of in vitro antimalarial activity can not directly describe the actual events in human body. So, it is possible for a plant that is active as an antimalarial in human to be inactive in an in vitro testing, and vice versa. Thirdly, certain plant may not be true antimalarial (antiplasmodial) that works to kill or inhibit the growth of Plasmodium. It may be more likely an indirect antimalarial (antipyretic, analgesic or anti-inflammatory) that works to heal the symptoms related to malaria, and therefore, the test showed no significant activity as antiplasmodial. As is known, traditional treatment of malaria is a symptomatic healing with the main goal to reduce heat or fever, so it is possible that a plant used in the traditional treatment of malaria is more likely antipyretic than antiplasmodial. ${ }^{21,22}$ The plants that have antimalarial properties can show a direct effect on Plasmodium by inhibiting the growth of Plasmodium or killing it, or giving indirect effects on the relationship between the human body and parasites. A plant that inhibiting or killing Plasmodium is called antiplasmodial or true antimalarial. The other plants may serve as indirect antimalarial, that affect the relationship between the human body as a host and the Plasmodium, for example as immunostimulant or antipyretic, or causing hemolysis and changes in membrane structure which results in the inhibition of the growth of Plasmodium.

Searching of previous studies in any publications showed that this report of antiplasmodial activity of Neoalsomitra podagrica Steenis and Fatoua pilosa Gaudich. against Plasmodium falciparum 3D7 strain is the first. There were no studies of the antimalarial activity of these two plants carried out by other researchers before. The F. pilosa Gaudich. was only reported to have pharmacological activity as an antimycobacterial, ${ }^{24}$ while $N$. podagrica Steenis has no known its pharmacological activities. Therefore, it is an open chance to make a further evaluation of the antimalarial activity of these two plants, and to identify antimalarial active compound(s) of them.

\section{Phytochemicals contenc of the extracts}

The results of phytochemical analysis using GC-MS are as shown in Table 3. From this table, we can see that for overall, these 11 extracts contain various types of natural products, such as alkaloids, terpenoids, steroids, coumarins, alcohols, thiols, phenolics, aldehydes, fatty acids, esters, etc. Several previous studies showed that many secondary plant metabolites such as alkaloid, flavonoid, xantone, quassinoid, triterpene and sesquiterpene have antiplasmodial activity, and thus, have the potential to be developed as antimalarial. ${ }^{4,17}$ Although the types and amounts of compounds that can be identified by GC-MS are limited to the volatile compounds, the results showed that there are a quite number of compounds that were previously unknown to be contained in each of the extracts, for example the alkaloid brucine in the leaves of Melia azedarach L. Some of the compounds identified from those eleven plants extracts have been known to have antiplasmodial activity, such as alstonine, alstomacroline, pleiocarpamine, lupeol, amyrin and brucine. ${ }^{13,15,17,25,26,27}$

\section{CONCLUSION}


There are at least 50 plant species used by the Tetun ethnic people as oral antimalarial medicine. The Alstonia scholaris (L.) R.Br., Alstonia spectabilis R.Br., Calotropis gigantea (L.) R. Br., Cleome rutidosperma DC., Fatoua pilosa Gaudich., Jatropha curcas L., Melia azedarach L., Neoalsomitra podagrica Steenis, Physalis angulata L., Plumeria alba L. and Strychnos ligustrina Blume are some of the high cited plants. These 11 plants have been proven to have antiplasmodial activity, ranged from strong to weak antiplasmodial. The $P$. angulata L., J. curcas L., A. spectabilis R.Br., N. podagrica Steenis and F. pilosa Gaudich. may have a potency to be developed as new sources of antimalarials.

The novelty of this study is the fact that $N$. podagrica Steenis have never been reported used as antimalarial in other traditional medicine systems elsewhere. And this result is the first publication of the antiplasmodial activity of $N$. podagrica Steenis and F. pilosa Gaudich. against Plasmodium falciparum 3D7 strain.

\section{ACKNOWLEDGEMENT}

This study was supported by The Directorate of Research and Community Service, Ministry of Research, Technology and Higher Education, Republic of Indonesia (Research Contract No. 0668/K8/KM/2018), Father Rector of Widya Mandira Catholic University, and Head of Yayasan Pendidikan Katolik Arnoldus Kupang. Thank to all the informants for their participation in our field study in Belu and Malaka Districts, and to the analyst of Malaria Laboratory, Institute of Tropical Diseases, Airlangga University, for her assistance in the examination of antiplasmodial activity.

\section{Conflict of interests}

We declare that we have no any conflict of interests in publishing this article.

\section{REFERENCES}

1. Verpoorte R. Medicinal plants: A renewable resource for novel leads and drugs. In: Ramawat KG, ed. Herbal drugs: Ethnomedicine to modern medicine. Berlin Heidelberg: Springer-Verlag, 2009.

2. Schippmann U, Leaman DJ, Cunningham AB. Plants as source of medicines: New perspectives. In: Bogers RJ, Craker LE, Lange D, eds. Medicinal and aromatic plants Agricultural, commercial, ecological, legal, pharmacological and social aspects. Dordrecht: Springer, 2006.

3. Ramawat KG, Goyal S. The Indian herbal drugs scenario in global perspectives. In: Ramawat KG, Merillon JM, eds. Bioactive molecules and medicinal plants. Berlin: Springer, 2008.

4. Schwikkard S, van Heerden F. Antimalarial activity of plant metabolites. Nat Prod Rep. 2002; 19: 675-692

5. Htut ZW. Artemisinin resistance in Plasmodium falciparum malaria. $N$ Engl J Med. $2009 ; 361 ; 1807-1808$.

6. Akuodor GC, Ajoku GA, Ezeunala MN, Chilaka KC, Asika EC. Antimalarial potential of the ethanolic leaf extract of Pseudocedrala kotschyi. J Acute Dis. 2015; 14: 23 27.

7. Willcox ML, Bodeker G. Traditional herbal medicines for malaria. Br Med J. 2004; 329: 1156-1159.

8. Lemma MT, Ahmed AM, Elhady MT, Ngo HT, Vu TL, Sang TK, Campos-Alberto E, Sayed A, Mizukami S, Na-Bangchang K, Huy NT, Hirayama K, Karbwang J. Parasitol Int. 2017; 66(6): 713-720.

9. Taek MM, Prajogo BEW, Agil M. Plants used in traditional medicine for treatment of malaria by Tetun ethnic people in West Timor Indonesia. Asian Pac J Trop Med. 2018; 11(11): 630-637.

10. Drees EM. List of Tree and Shrub Names from Timor. Bogor: Balai Penyelidikan Kehutanan, 1950. 
11. Trager W, Jenssen JB. Human malaria parasites in continuous culture. Science. 1976; 193: 673-675.

12. Ouattara Y, Sanon S, TraorÃ Y, Mahiou V, Azas N, Sawadogo L. Antimalarial activity of Swartzia madagascariensis Desv. (Leguminosae), Combretum glutinosum Guill. $\&$ Perr. (Combretaceae) and Tinospora bakis Miers. (Menispermaceae), Burkina Faso medicinal plants. Afr. Trad. CAM. 2006; 3(1): 75-81.

13. Lusakibanza M, Mesia G, Tona G, Karemere S, Lukuka A, Tits M, Angenot L, Frédérich M. In vitro and in vivo antimalarial and cytotoxic activity of five plants used in Congolese traditional medicine. J Ethnopharmacol. 2010; 129(3): 398-402.

14. Sarkiyayi S, Zailani HA, Simon JG. Effects of aqueous stem bark extract of Jatropha curcas on some biochemical indices of mice infected with Plasmodium berghei Am J Biochem. 2016; 6(5): 130-135.

15. Johnson NB, Ameyaw EO, Kyei S, Aboagye B, Asare K, Afoakwah R, Boye A, Donfack JH. In vivo antimalarial activity of stem bark extracts of Plumeria alba against Plasmodium berghei in imprinting control region mice. Rep Parasitol. 2013; 3. 19-25.

16. Abdillah S, Tambunan RM, Farida Y, Sandhiutami NMD, Dewi RM. Phytochemical screening and antimalarial activity of some plants traditionally used in Indonesia. Asian Pac J Trop Dis. 2015; 5(6): 454-457.

17. Saxena S, Pant N, Jain DC, Bhakuni RS. Antimalarial agents from plant sources. Current Science. 2003; 85(9): 1314-1326.

18. Murnigsih T, Subeki, Matsuura H, Takahashi K, Yamasaki M, Yamato O, Maede Y, Katakura K, Suzuki M, Kobayashi S, Chairul, Yoshihara T. Evaluation of the inhibitory activities of the extracts of Indonesian traditional medicinal plants against Plasmodium falciparum and Babesia gibsoni. J Vet Med Sci. 2005; 67(8);829-831.

19. Chan EW, Wong SK, Chan HT. Apocynaceae species with antiproliferative and/or antiplasmodial properties: A review of ten genera. I Integr Med. 2016; 14(4): 269-284.

20. Bose A, Smith PJ, Lategan CA, Gupta JK, Si S. Studies on in vitro antiplasmodial activity of Cleome rutidosperma. Acta Pol Pharm. 2010; 67(3): 315-318.

21. Taek MM, Prajogo BEW, Agi M. Ethnomedicinal plants used for the treatment of malaria in Malaka, West Timor. J Young Pharm. 2018; 10(2): 187-192.

22. Taek MM, Prajogo BEW, Agil M. Ethnomedicine of Tetun ethnic people in West Timor Indonesia: Philosophy and practice in the treatment of malaria. Integr Med Res. 2019; 8: $139-144$.

23. Mambu L, Grellier P. Antimalarial compounds from traditionally used medicinal plants. In: Colegate SM, Molyneux RJ, eds. Bioactive natural products: Detection, isolation and structural determination 2nd edition. New York: CRC Press; 2007.

24. Chiang CC, Cheng MJ, Peng CF, Huang HY, Chen IS. A novel dimeric coumarin analog and antimycobacterial constituents from Fatoua pilosa. Chemistry \& Biodiversity. 2010:7(7): 1728-1736.

25. Widiastuti Y, Widodo H, Supriyati N, Subositi D, Haryanti S, Adi MBS, Damayanti A, Hidayat T. 100 top tanaman obat Indonesia. Jakarta: Kemenkes RI, 2011.

26. Abiodun O, Gbotosho G, Ajaiyeoba E, Happi T, Falade M, Wittlin S, Sowunmi A, Brun R, Oduola A. In vitro antiplasmodial activity and toxicity assessment of some plants from Nigerian ethnomedicine. Pharm Biol. 2011; 49(1): 9-14.

27. Sura J, Sumeet D, Raghvendra D. Pharmacological, phytochemical, and traditional uses of Plumeria alba L. an Indian medicinal plant. SPER J Anal \& Drug Reg. 2016: 14-17.

Table 1. Plants used by the Tetun ethnic people for the treatment of malaria 


\begin{tabular}{|c|c|c|c|c|}
\hline Botanic name & Family & Local name & $\begin{array}{l}\text { Plants' part } \\
\text { used }\end{array}$ & $\begin{array}{l}\text { Frequency } \\
\text { of citation } \\
\mathrm{n}(\%)^{*}\end{array}$ \\
\hline Strychnos ligustrina Blume & Loganiaceae & Bakumoru & $\begin{array}{l}\text { Wood, stem } \\
\text { bark }\end{array}$ & $32(34.04)$ \\
\hline Calotropis gigantea (L.) R. & Asclepediaceae & Fuka & Root & $23(24.47)$ \\
\hline Cleome rutidosperma DC. & Capparaceae & Lakaur & Whole plant & $17(18.09)$ \\
\hline Physalis angulata L. & Solanaceae & Babotore & Whole plant & $17(18.09)$ \\
\hline Carica papaya L. & Caricaceae & Dila & Leaves & $16(17.02)$ \\
\hline Alstonia spectabilis R.Br. & Apocynaceae & Kroti metan & Stem bark & $16(17.02)$ \\
\hline Alstonia scholaris (L.) R.Br. & Apocynaceae & Kroti mutin & Stem bark & $13(13.83)$ \\
\hline Melia azedarach L. & Meliaceae & Samer & $\begin{array}{l}\text { Leaves, stem } \\
\text { bark }\end{array}$ & $13(13.83)$ \\
\hline Fatoua pilosa Gaudich. & Moraceae & Lorowen & Root & $7(7.45)$ \\
\hline Jatropha curcas L. & Euphorbiaceae & $\begin{array}{l}\text { Badut } \\
\text { malaka mutin }\end{array}$ & Stem bark & $6(6.38)$ \\
\hline Swietenia macrophylla King & Meliaceae & Mahoni & Seed & $6(6.38)$ \\
\hline Plumeria alba L. & Apocynaceae & Mukrin & Stem bark & $6(6.38)$ \\
\hline Momordica balsamina L. & Cucurbitaceae & Bria fuik & Leaves, fruit & $5(5.32)$ \\
\hline Neoalsomitra podagrica Steenis & Cucurbitaceae & Masin borat & Root & $4(4.26)$ \\
\hline Wrightia pubescens R.Br. & Apocynaceae & Ialitin feto & $\begin{array}{l}\text { Leaves, root, } \\
\text { stem bark }\end{array}$ & $3(3.19)$ \\
\hline $\begin{array}{l}\text { Tabernaemontana pandacaqui } \\
\text { Lam. }\end{array}$ & & Lalitin mane & Stem bark & $3(3.19)$ \\
\hline Aegle marmelos (L.) Correa & Rutaceae & Dilabutak & $\begin{array}{l}\text { Stem bark, } \\
\text { root, leaves }\end{array}$ & $3(3.19)$ \\
\hline $\begin{array}{l}\text { Andrographis paniculata } \\
\text { (Burm.f.) Nees. }\end{array}$ & Acanthaceae & Karlulu & Whole plant & $2(2.13)$ \\
\hline Cassia fistula $\mathrm{L}$. & Fabaceae & Liman tohar & Stem bark & $2(2.13)$ \\
\hline Cassia siamea Lam. & Fabaceae & Krui & $\begin{array}{l}\text { Leaves, stem } \\
\text { bark }\end{array}$ & $2(2.13)$ \\
\hline Coccinia grandis (L.) & Cucurbitaceae & Kabasa & Leaves & $2(2.13)$ \\
\hline Ficus callosa Willd. & Moraceae & Salur & Stem bark & $2(2.13)$ \\
\hline Ficus hispida L.f. & Moraceae & Baulenuk & Leaves & $2(2.13)$ \\
\hline Phyllanthus niruri L. & Phyllanthaceae & Renes & Whole plant & $2(2.13)$ \\
\hline Acacia leucophloea (Roxb.) Willd. & Fabaceae & Besak & Stem bark & $1(1.06)$ \\
\hline Blumea balsamifera (L.) DC. & Compositae & Fafok & Stem bark & $1(1.06)$ \\
\hline Bridelia ovata Decne. & Euphorbiaceae & Knabu & Leaves & $1(1.06)$ \\
\hline Brucea javanica (L.) Merr. & Simaroubaceae & Ai lakar & $\begin{array}{l}\text { Leaves, stem } \\
\text { bark, root }\end{array}$ & $1(1.06)$ \\
\hline Capsicum frutescens L. & Solanaceae & Masimanas & Fruit & $1(1.06)$ \\
\hline Ceiba pentandra (L.) Gaertn. & Malvaceae & Kabidawa & Leaves & $1(1.06)$ \\
\hline Curcuma domestica Val. & Zingiberaceae & Kinur & Rhizome & $1(1.06)$ \\
\hline Dendropthoe pentandra (L) Miq. & Loranthaceae & Tau tiu ten & Leaves & $1(1.06)$ \\
\hline $\begin{array}{l}\text { Dysoxylum gaudichaudianum (A. } \\
\text { Juss.) Miq. }\end{array}$ & Meliaceae & Meda lasan & Leaves & $1(1.06)$ \\
\hline Garuga floribunda Decne. & Burseraceae & Feu & Stem bark & $1(1.06)$ \\
\hline Gossypium herbaceum L. & Malvaceae & $\begin{array}{l}\text { Kabas fuan } \\
\text { mean }\end{array}$ & Root & $1(1.06)$ \\
\hline
\end{tabular}




\begin{tabular}{|c|c|c|c|c|}
\hline Grewia koodersiana Burrett. & Tilliaceae & Lenok & Root & $1(1.06)$ \\
\hline Gymnopetalum chinense (Lour.) & Cucurbitaceae & Kolokoen & Root & $1(1.06)$ \\
\hline \multicolumn{5}{|l|}{ Merr. } \\
\hline Imperata cylindrica (L.) P.Beauv. & Poaceae & Hae manlain & Root & $1(1.06)$ \\
\hline Indigofera suffruticosa Mill. & Fabaceae & Taun & Leaves & $1(1.06)$ \\
\hline Jatropha gossypifolia L. & Euphorbiaceae & $\begin{array}{l}\text { Badut } \\
\text { malaka mean }\end{array}$ & Stem bark & $1(1.06)$ \\
\hline Morinda citrifolia L. & Rubiaceae & Nenuk & $\begin{array}{l}\text { Leaves, fruit, } \\
\text { stem bark }\end{array}$ & $1(1.06)$ \\
\hline Nauclea orientalis (L.) L. & Rubiaceae & Kafiru & Stem bark & $1(1.06)$ \\
\hline Piper cubeba L.f. & Piperaceae & Kunus aleten & Leaves & $1(1.06)$ \\
\hline Sterculia foetida L. & Sterculiaceae & Abano & Stem bark & $1(1.06)$ \\
\hline Tamarindus indica L. & Fabaceae & Sukaer & Leaves & $1(1,06)$ \\
\hline Uvaria rufa Blume. & Annonaceae & Koke & Root & $1(1.06)$ \\
\hline Wendlandia burkillii Cowan & Rubiaceae & Katimun & Stem bark & $1(1.06)$ \\
\hline Ziziphus timoriensis DC. & Rhamnaceae & Ai sisi & Leaves & $1(1.06)$ \\
\hline Not identified & Not identified & Moat tiris & Leaves & $1(1.06)$ \\
\hline Not identified & Not identified & Uas laomea & Tuber & $1(1.06)$ \\
\hline
\end{tabular}

Note:* The total percentage is greater than $100 \%$ because each informant $(N=94)$ mentioned more than one plant.

Figure 1. Graphical comparison of inhibitory ability of the plants extract on Pasmodium falciparum 3D7 strain in vitro

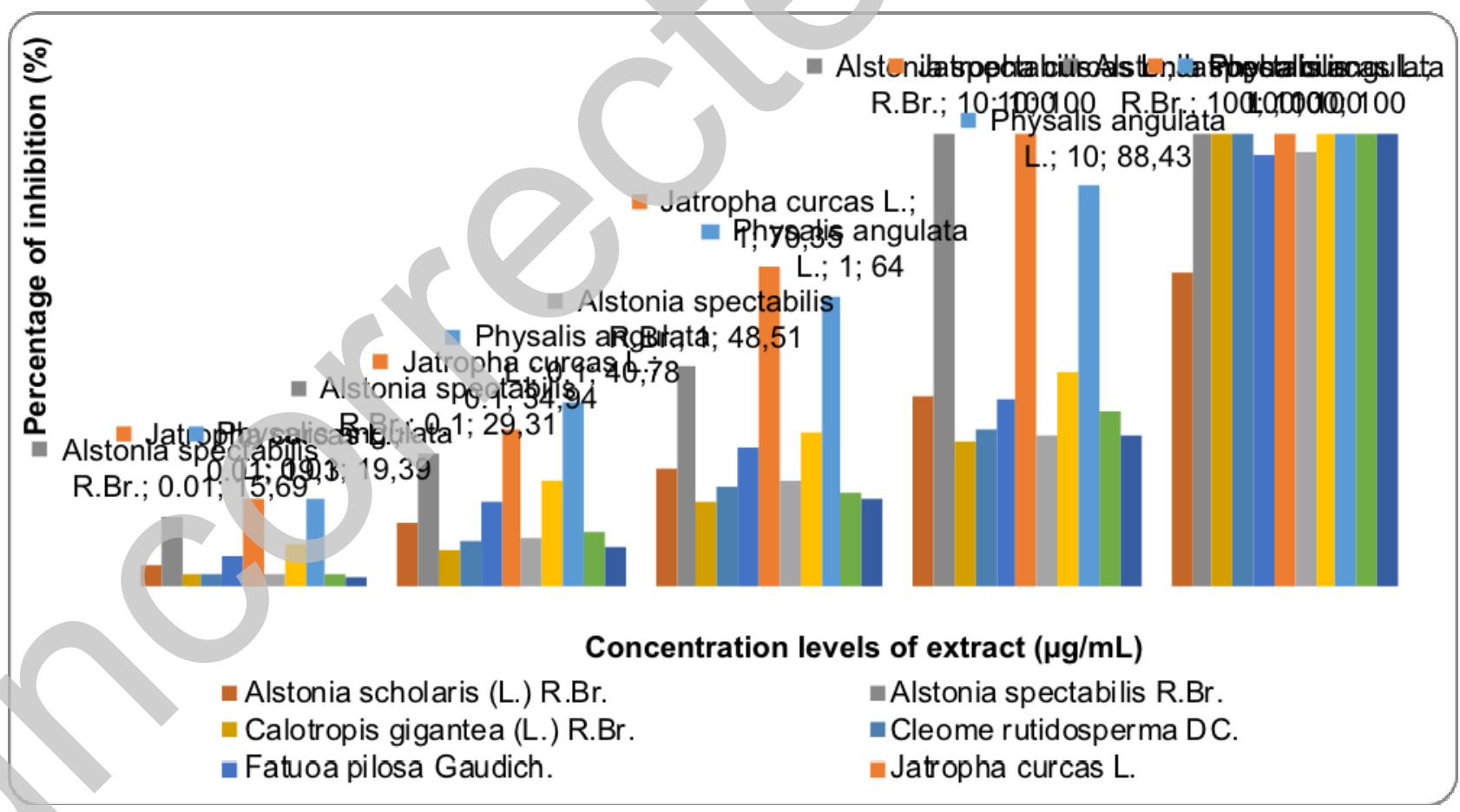

Table 2. Antiplasmodial activity of the plants extract

\begin{tabular}{lllllll}
\hline Plant extract & \multicolumn{4}{l}{$\begin{array}{l}\text { Inhibition percentage of extract on Plasmodium }(\%) \\
\text { at each level of concentration }(\mu \mathrm{g} / \mathrm{mL})\end{array}$} & $\begin{array}{l}\text { IC50 } \\
\end{array}$ \\
\cline { 2 - 6 } & 0.01 & 0.1 & 1.0 & 10 & 100 & \\
\hline Alstonia scholaris (L.) R.Br. & 5.06 & 14.52 & 26.20 & 41.89 & 69.26 & 15.46
\end{tabular}




\begin{tabular}{lllllll} 
Alstonia spectabilis R.Br. & 15.69 & 29.31 & 48.51 & 100.00 & 100.00 & 1.23 \\
Calotropis gigantea (L.) R.Br. & 2.96 & 8.43 & 18.96 & 32.44 & 100.00 & 66.49 \\
Cleome rutidosperma DC. & 3.04 & 10.25 & 22.09 & 34.96 & 100.00 & 54.25 \\
Fatuoa pilosa Gaudich. & 6.70 & 18.69 & 30.78 & 41.39 & 95.56 & 24.92 \\
Jatropha curcas L. & 19.30 & 34.94 & 70.35 & 100.00 & 100.00 & 0.22 \\
Melia azedarach L. & 2.96 & 10.78 & 23.74 & 33.22 & 95.91 & 63.52 \\
Neoalsomitra podagrica Steenis & 9.74 & 23.39 & 34.26 & 47.74 & 100.00 & 11.60 \\
Physalis angulata L. & 19.39 & 40.78 & 64.00 & 88.43 & 100.00 & 0.22 \\
Plumeria alba L. & 2.98 & 12.45 & 20.88 & 39.04 & 100.00 & 36.39 \\
Strychnos ligustrina Blume & 2.20 & 8.56 & 19.19 & 33.33 & 100.00 & 63.91 \\
\hline
\end{tabular}

Table 3. Phytochemical contents of the plants'extracts identified using GC-MS

\begin{tabular}{|c|c|c|c|}
\hline Plant's extract & $\begin{array}{l}\text { Ret.Time } \\
(\mathrm{min})\end{array}$ & Compound & $\begin{array}{l}\text { Area } \\
(\%)\end{array}$ \\
\hline \multirow{30}{*}{$\begin{array}{l}\text { Alstonia scholaris (L.) } \\
\text { R.Br. }\end{array}$} & 20.63 & $n$-Hexadecanoic acid & 0.15 \\
\hline & 22.25 & Z-9-Oxtadecenoic acid & 0.20 \\
\hline & 22.41 & Linoleic acid ethyl ester & 0.08 \\
\hline & 26.93 & $\begin{array}{l}\text { 4, 11-dimethoxy-1H-cyclopent }[\mathrm{b}] \text { anthracene- } \\
2,5,10(3 \mathrm{H}) \text {-trione }\end{array}$ & 0.14 \\
\hline & 27.86 & $\begin{array}{l}\text { 2, 2-dimethyl-6,11-dioxo- } 2,3,6,11 \text { - } \\
\text { tetrahydroanthra[1, 2-b]furan-4-carbaldehyde }\end{array}$ & 0.13 \\
\hline & 27.94 & Pleiocarpamine & 0.11 \\
\hline & 28.50 & $\begin{array}{l}\text { E-3,3'-bis-ethylmercapto-1,1'- } \\
\text { bisoindolylidene }\end{array}$ & 0.18 \\
\hline & 29.22 & Dihy droxycrinane & 0.22 \\
\hline & 30.91 & Campesterol & 0.66 \\
\hline & 31.33 & 2, 2-dimethyl-cholest-4-en-3-one & 0.83 \\
\hline & 32.24 & 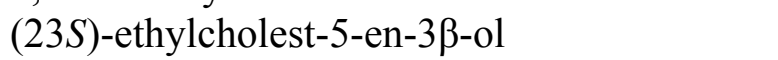 & 0.97 \\
\hline & 32.69 & $\beta$-Amyrin & 27.61 \\
\hline & 33.17 & Aristolone & 5.12 \\
\hline & 33.77 & Isomultiflorenyl acetate & 0.54 \\
\hline & 34.25 & Maragenin I acetate & 18.94 \\
\hline & 35.17 & Lupenyl acetate & 32.03 \\
\hline & 35.32 & Dihydroagnosterol acetate & 0.11 \\
\hline & 35.85 & Friedoursan-3-one & 0.11 \\
\hline & 18.33 & Coniferol & 0.71 \\
\hline & 20.67 & $n$-Hexadecanoic acid & 0.53 \\
\hline & 22.26 & E-9-Octadecanoic acid & 0.46 \\
\hline & 25.85 & Strictamine & 0.44 \\
\hline & 26.30 & Eupomatenoid-17 & 0.32 \\
\hline & 26.43 & Pleiocarpamine & 1.70 \\
\hline & 26.50 & 10-Aza-8-oxyprotoberberine & 2.54 \\
\hline & 27.07 & $\begin{array}{l}\text { 2, 5-bis(3,5-dimethyl-4-methoxyphenyl)- } \\
\text { thiophene }\end{array}$ & 0.26 \\
\hline & 27.14 & Fluorocarpamine & 0.43 \\
\hline & 28.18 & Vincamajine & 2.09 \\
\hline & 28.70 & Alstomacroline & 10.27 \\
\hline & 30.36 & Homoegonol & 0.39 \\
\hline
\end{tabular}


1-amino-8-methyl-3, 6-diazahomodamantan9-ol

Aristolone

1, 1-diethoxy-ethane $\mathrm{Br}$.

Ethyl hexadecanoate

Cleome rutidosperma DC.

Urs-12-en-24-oic acid, 3-oxo-, methyl ester $\quad 0.54$

$\alpha$-Amyrin acetate

0.98

Dammaradienyl acetate $\quad 0.49$

$\beta$-Amyrene

0.26

1, 1-diethoxy-ethane $\quad 0.20$

Angelicin 6.57

$n$-Hexadecanoic acid $\quad 0.18$

Heraclin $\quad 0.48$

Seselin 0.55

Ethyl oleate 0.13

Brayelin 0.12

Vincanine $\quad 1.79$

Strictamine $\quad 0.19$

Cycloartenol 0.33

Friedelin $\quad 0.48$

Aristolone $\quad 3.49$

$\beta$-Amyrin $\quad 2.55$

Lupene-3-one $\quad 14.04$

Lupeol $\quad 15.40$

Urs-12-en24-oic acid, 3-oxo-, methyl ester $\quad 7.76$

Fern-7-en-3 $\beta$-ol $\quad 1.75$

Moretenol 0.67

$\alpha$-Amyrin acetate $\quad 12.38$

9, 19-cyclolanost-7-en-3-ol $\quad 1.15$

33-Lup-20 (29)-en-3-ol acetate $\quad 1.15$

2,4-bis(1-phenylethyl)phenol $\quad 0.47$

Isocryptotanshinon 1.08

5-methoxy-6-[1-(4-ethoxyphenyl)ethyl]-1,3benzodioxol 1.02

7-bromo-cycloisolongifolene $\quad 1.07$

Ferruginol methyl ether $\quad 1.95$

$31.88 \quad 13,27$-cycloursane 2.85

32.93 4, 14-dimethyl-9, 9-cyclocholestan-3-one $\quad 0.55$

Melia azedarach L. $\quad 2.10 \quad$ 2-Allyl-1,3-dioxolan 0.19

$19.05 \quad$ Ethylpentylacetylene 0.14

$20.51 \quad n$-Hexadecanoic acid $\quad 0.81$

22.10 Methyl hexadeca-7,10,13-trienoate 0.56 


\begin{tabular}{|c|c|c|c|}
\hline & 22.15 & $(9 Z, 12 Z, 15 Z)$-octadecatrien-1-ol & 0.21 \\
\hline & 32.11 & $(22 E, 24 S)$-stigmasta-4,22-dien-6-one & 0.10 \\
\hline & 32.92 & 2,2-dimethylcholest-4-en-3-one & 0.35 \\
\hline & 35.09 & Dibenz[a,h]anthracene & 0.23 \\
\hline & 36.29 & Brucine & 0.96 \\
\hline & 39.54 & 4,6-di-m-tolyl-1H-[1,3,5]triazin-2-one & 0.28 \\
\hline \multirow{14}{*}{$\begin{array}{l}\text { Neoalsomitra podagrica } \\
\text { Steenis }\end{array}$} & 20.63 & $n$-Hexadecanoic acid & 0.61 \\
\hline & 22.26 & $9,12,15$-octadecatrien-1-ol & 0.99 \\
\hline & 22.48 & $n$-Octadecanoic acid & 0.58 \\
\hline & 27.62 & 2, 5, 8-trimethyl-1-naphtol & 0.27 \\
\hline & 28.25 & Plectrinon A & 0.43 \\
\hline & 29.21 & $\beta$-Tocopherol & 0.35 \\
\hline & 31.17 & 3-Phenoxyphenol & 0.56 \\
\hline & 31.96 & $3 \beta, 5 \alpha$-Stigmasta-7, 25-dien-3-ol & 7.94 \\
\hline & 32.46 & $3 \beta, 5 \alpha$-Stigmasta-7, 16-dien-3-ol & 2.43 \\
\hline & 33.53 & trans, cis-1,2,4-trimethylcyclohexane & 1.72 \\
\hline & 33.82 & Norolean-12-ene & 0.77 \\
\hline & 34.27 & 3-Methoxy-N-(4-chlorophenyl)sulfonyl & 127 \\
\hline & 34.51 & 1-chloro-4-(methylsulfonyl)-benzene & $\begin{array}{l}1.22 \\
3.91\end{array}$ \\
\hline & 34.80 & 1-(2-thienyl)-1-butanone & 2.06 \\
\hline \multirow[t]{4}{*}{ Physalis angulata L. } & 2.09 & 1, 1-diethoxy-ethane & 0.19 \\
\hline & 31.72 & Medroxyprogesterone acetate & 0.27 \\
\hline & 31.88 & 3ß-lupa-1, 20 (29)-dien-3-ol & 0.14 \\
\hline & 32.40 & Ergosta-4, 24 (28)-dien-3-one & 0.16 \\
\hline \multirow[t]{6}{*}{ Plumeria alba L. } & 2.10 & 1,1 -diethoxy-ethane & 0.16 \\
\hline & 31.25 & 3-keto-urs-12-ene & 0.37 \\
\hline & 31.82 & Friedooleanan-3-one & 1.07 \\
\hline & 32.99 & $\beta$-Amyrin acetate & 1.03 \\
\hline & 33.86 & 3ß-lup-20 (29)-en-3-ol acetate & 9.22 \\
\hline & 34.98 & Olean-18-en-28-oic acid, 3-oxo-, methyl ester & 0.10 \\
\hline \multirow[t]{2}{*}{ Strychnos ligustrina Blume } & 2.05 & 1, 1-diethoxy-ethane & 0.24 \\
\hline & 36.10 & Brucine & 0.73 \\
\hline
\end{tabular}

